$319 \mathrm{Ti}$ 基複合材料ブレードの低コスト製造プロセス開発

\title{
Development of low cost manufacturing process for Titanium matrix composite blade
}

○正 山田 毅、 都筑隆之、正 廣田 雅、河内幸雄、“山本伸一

（先進材料利用ガスジェネレータ研究所）

Takeshi YAMADA, Takayuki TSUZUKU, Masashi HIROTA, Yukio KAWACHI, and Shinichi YAMAMOTO, Research Institute of Advanced Material Gas-Generator, 1-13-4 Kitaohtsuka, Toshima-ku, Tokyo, 170-0004, Japan

\begin{abstract}
In development of continuous fiber reinforced titanium alloy matrix composites (TMCs), the enormous production cost resulting from preliminary forming and elaborate tooling for consolidation is the fatal difficulty for practical application. In order to reduce the production cost, superplastic-formable TMC sheets (SCS-6/Ti-4.5Al-3V-2Fe-2Mo) were developed, and deformation characteristics and cavitation behavior were investigated. In this study a new low-cost-manufacturing process for titanium matrix composite blade has been developed. This process consists of three steps : (i) consolidation of flat TMC panels of $20 \mathrm{~mm}$ thickness, (ii) superplastic forming to twist the TMC panel and (iii) machining of the twisted TMC to a final blade configuration. Using this process, production cost of a TMC blade can be reduced to $1 / 5$ of the cost for the TMC blade fabricated by the conventional manufacturing process.
\end{abstract}

Key words : Titanium Matrix Composite, Superplastic Forming, Blade, Production Cost

\section{1. 粕言}

長瀻維強化 $\mathrm{Ti}$ 基複合材料 (TMC) は高比強度・高比 剛性であることから航空宇宙用構造材料としての適用が

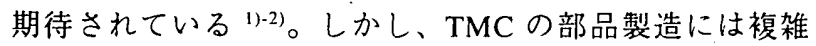
な治具や多くの加工工程を必要とする為、TMC の部品 製造コス卜は非常に高く、これが実用化への大きな妨げ となっている。そこで著者らは、TMC 板材を直接超塑 性成形することにより治具費や工程数を削減する低コス 卜加工法の開発を進めでき。これまでに超塑性成形可 能な TMC として SCS-6/SP-700 材を新たに開発し、本材 の超塑性変形特性及び欠陷発生挙動を調心゙、欠陥発生を 防止できる超塑性成形法としてダイアフラム成形法 (DF 法）を選定した ${ }^{3)}$ 。DF 法は TMC 板材を成形金型上に置 き、それより上側に配置したSP-700 板材を Ar ガス圧バ ルジ成形し、これに押された TMC が金型に押しつけら れて成形されるという方法であり、比較的低応力・低ひ

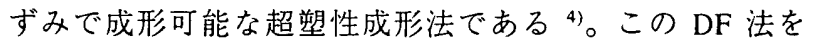
用いて TMC ブレードを試作し、回転試験による破断強 度評価を行ったところ、設計要求值を上回る破断強度を 有することを確認した ${ }^{5)}$ 。試作したブレードの製造プロ セスは、(1) $8.5 \mathrm{~mm}$ 板厚の TMC 板材の製作、(2)翼面板厚 分布に対応した変肉機械加工、(3)DF 法による超塑性成 形、(4)恒温鍛造による形状矯正、(5)成形後 TMC への $\mathrm{Ti}$ 合金ブロックの拡散接合、(6)最終形状への機械加工とい う6段階の工程で構成されていた。このうち(5)の拡散接 合はブレー.ド付け根部（ルート部）の板厚確保のために 上下一対の $\mathrm{Ti}$ 合金ブロックを拡散接合しているが、複 雑な形状を有する TMC 板材との拡散接合は難しく、多 くの未接合部が認められた。本報告では、拡散接合不良 をなくす為に、製造プロセスから拡散接合工程を省き、
代わりに TMC 板材の板厚を厚肉化 $(20 \mathrm{~mm})$ するなど の改良を行ったブレード製造プロセスについて報告する。

\section{2. 実験方法}

本試験で用いた TMC ブレードの製造プロセスは、(1) $20 \mathrm{~mm}$ 板厚の TMC 板材の製作、(2)DF 法による超塑性成 形、(3)最終形状への機械加工という3 段階の工程で構成 されている。前回試作試験での製造プロセスが6段階の 工程で構成されているのに対して、新たな製造プロセス では工程数を半分にしている。素材の構成材料には Textron Systems 社製の CVD 系 SiC 繊維である SCS-6を 強化材とし、マトリックス材には NKK 社製の $\beta$ rich $\alpha$ $+\beta$ 型 $\mathrm{Ti}$ 合金の SP-700（Ti-4.5Ai-3V-2Fe-2Mo）を用い た。TMC 板材はFoil/Fiber/Foil プロセスで製作し、その 層構成は Woven プリフォーム（一方向に並べた SCS-6 繊維を幅 $100 \mu \mathrm{m}$ 程度の Ti-Nb 合金リボンを横糸として 編んだもの）を 19 層、0.2mm 板厚の SP-700 箔 20 層を 交互に積層し、その外側に上下一枚ずつの $0.5 、 1.5 、 6 \mathrm{~mm}$ 板厚のSP-700.板を重ねたものとなっている。この積層 体をステンレス製カプセル内に真空封止した後、熱間静 水圧加圧処理 (HIP 処理) により複合化した。HIP 処理 条件は温度 $1048 \mathrm{~K}$ 、保持時間 $2 \mathrm{~h} 、 \mathrm{Ar}$ ガス圧 $120 \mathrm{MPa}$ と した。TMC 素材の超塑性成形は、Ar ガスを用いて 1048K において、多ヤフラムとなる SP-700 板の最大ひずみ 速度が $5 \times 10^{-5} \mathrm{~s}^{-1}$ となる条件で行った。最後に成形後 TMC 素材を機械加工により最終形状とした。また試作 した TMCブレードの形状測定を行うとともに、強化繊 維配置状況を調べるためにX線透過像撮影を行った。

\section{3. 実験結果}


Fig.1に試作したTMCブレードの外観を示す。本ブレ 一ドの加工公差要求は、翼面の加工公差は土0.1 mm で あり、ブレードのねじり角公差は土0.25 度である。試作 品の形状測定からこれらの加工公差を渵足していること が確認された。Fig.2 に試作したブレードのX 線透過像 を示す。透過像のコントラストは主にブレードの板厚に 対応しており、厚い部分は黒く、薄い部分は白くなって いる。翼面中央部の白く見える部分には強化繊維が写し 出されている。強化纎維を構成する $\mathrm{Si}$ 及び C 原子が、 マトリックスを構成する $\mathrm{Ti}$ 等の金属元素に比べて軽い 元素で構成されているために、強化繊維はマトリックス に比べて X 線の透過性が良い。そのため、X 線透過像 撮影により内部の強化繊維配置状況が確認でき、その配 置は図面要求形状に対してさ1 mm 程度の精度で配置し ていた。

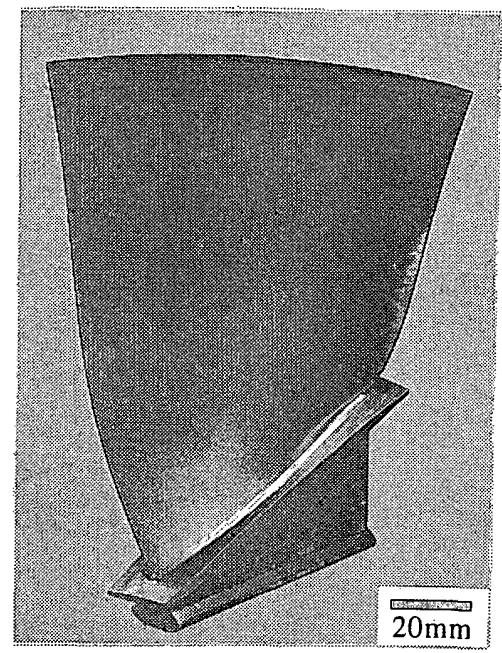

Fig.1 Appearance of the TMC blade

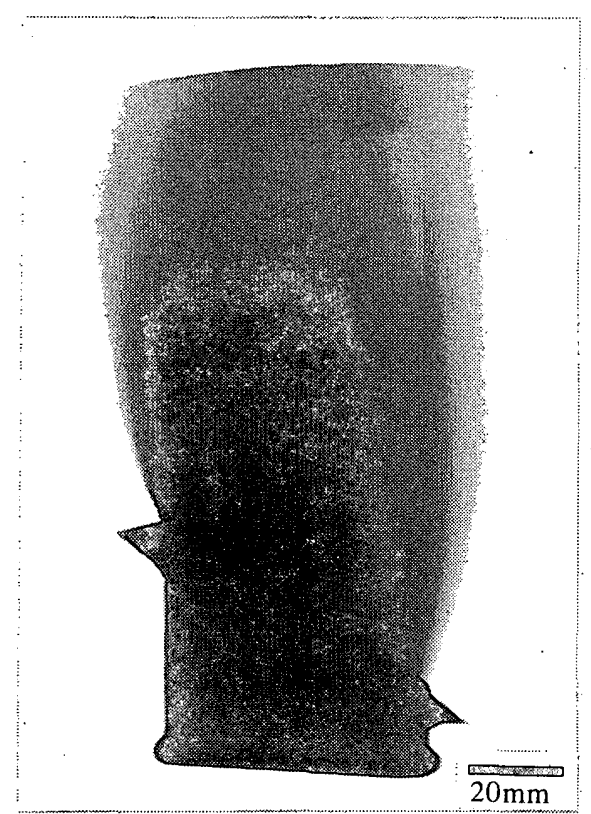

Fig.2 X-ray photograph of the TMC blade.

\section{4.製甶コスト低淢効果}

本研究で新たに開発した TMC ブレード製造プロセス は、3工程で構成された比較的シンプルなプロセスとな
っており、TMC ブレードの製造コストを大幅に削減で きると考えられる。Fig.3に三種類の製造プロセスによ る TMC ブレードの製造コストを比較した結果を示す。 著者らはこれまで三種類の製造プロセスにより TMCブ レードの試作を行ってきている。Fig.3 中の従来プロセ スとは、箔を熱間予備成形後、積層し、ネットシェイプ 複合化を行って素材を製作し、機械加工により最終形状 とするものである。新プロセスとは、上述した 6 工程か らなる超塑性加工を利用したプロセスである。Fig.3の コスト比較は従来プロセスでの製造コストを $100 \%$ とし た場合の割合で示し、TMCブレードを 10 体製造した場 合における1体当たりの製造コストを算出した。本研究 で開発したプロセスは従来プロセスに比べて、製造コス トを $1 / 5$ 程度に削減でき、新プロセスと比較しても $40 \%$ 程度まで低コスト化できた。本研究で開発したプロセス におけるコスト低減効果が最も大きかったのは機械加工 費である。他のプロセスではルート部に Ti 合金ブロッ クを拡散接合している為に素材形状が複雑となり、機械 加工工程も複雑で加工費が高くなっていた。本研究では 素材がほほ均一な板厚を有する板となったことで機械加 工が容易となり、加工費を大幅に削減できた。また加工 工程が少なくなったことで、治具費、複合化費及び成形・ 接合費が抑制できた。本研究で開発したプロセスを用い て数百体の TMC ブレードを製作した場合には、スケー ルメリットが出て治具費が殆どなくなり、さらに材料費 も大幅に抑制できることから、従来プロセスの $1 / 10$ 程 度まで製造コストを低減できると思われる。

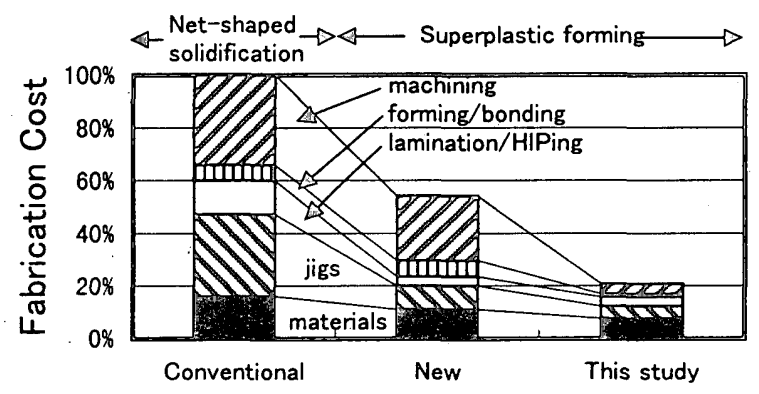

Fabrication Processes

Fig.3 Comparison of the fabrication costs among the conventional, the improved and the new fabrication process for the TMC blade model.

\section{5. 结言}

超塑性成形を利用した長瀻維強化複合材料ブレードの 製造プロセスを新たに開発し、設計要求を満足するモデ ル部品の試作に成功した。さらに本プロセスによりブレ 一ド製造コストを従来に比べて $1 / 5$ 程度に削減できるこ とを確認した。

\section{参考文献}

1) S.Mall et al. : Titanium Matrix Composites, (1998), pp.122.

2) C.M.Ward-Close et al. : Mater. Sci. Eng., A263, (1999), 314-318.

3) T.Yamada et al. : Materials and Manufacturing Processes, 15, (2000), 347-358.

4) R.J.Stracey et al. : Proc. of ICSAM-94, (1994), pp.725730.

5) 山田ほか：日本金属学会誌，64-10, (2000).印刷中 